\title{
In Vitro Induction of Flower Mutation in Catharanthus roseus Using Gamma Irradiation
}

\author{
El-Mokadem, Hoda E. 1
}

\begin{abstract}
The purpose of this study was to study the effect of gamma irradiation and in vitro culture on mutation induction of flower color in Catharanthus roseus. A number of plants were regenerated from irradiated internode explant. Tow cultivars from previous study Rosea and Alba, and four doses of gamma irradiation (0.0, $0.5,0.75$ and $1.0 \mathrm{~Gy}$ ) were applied. Obtained results indicated that both 0.75 and $1.0 \mathrm{~Gy}$ irradiation doses were the most effective in inducing mutation in flower shape and color, while the dose of $0.5 \mathrm{~Gy}$ was effective in inducing mutation in leaf form.
\end{abstract}

Key words: Catharanthus roseus, irradiation dose, mutations.

\section{INTRODUCTION}

Catharanthus roseus is an important medicinal plant, commonly known as Madagascar periwinkle. It is a perennial, evergreen herb, $30-100 \mathrm{~cm}$ height that was originally native to the island of Madagascar. It has been widely cultivated for hundreds of years and can now be found growing wild in the world warmest regions. The leaves are glossy, dark green (1-2 inch long), oblong-elliptic, acute, rounded apex; flowers white to pinkish purple in terminal or axillary cymosely clusters; follicle hairy, many seeded, 2-3 cm long; seeds oblong, minute and black. The plant is commonly grown in gardens for beddings, borders and for mass effect. It blooms throughout the year and is propagated by seeds or cuttings. The blooms of natural wild plants are pale pink with a purple eye in the center. The plant has historically been used to treat a wide assortment of diseases. It was used as folk remedy for diabetes in Europe for centuries (Swanston-Flatt et al. 1989). It is also used as prevention of cancer, cancer treatment, reduction of high blood pressure, externally against nose bleeding.

Mutation breeding of ornamental plants has been successfully applied for varietal improvement of many crop species. Some problems remain in inducing mutations of vegetative propagated plants, such as chimera formation (Stewart and Dermen, 1970), relatively low mutation frequency, and a limited mutation spectrum (Broertjies and Van Harten, 1978).

Since Broetjies et al. (1976) proposed that in vitro regeneration could solve the problem of chimera formation; a mutation induction method using in vitro technique has been applied to certain chrysanthemums (De Jong and Custer, 1986; Huttema et al., 1991; Preil et al., 1991). This in vitro technique represents a great potential for mutation breeding. However, the problems with low mutation frequency and the limited mutation spectrum have remained unsolved. Recently, induction of mutations based on ionizing radiations is one of the major breeding approaches for plant improvement. More than 2,300 mutant varieties have been released using irradiation mutagenesis (Jain, 2005) and among them 566 represent ornamental plants. Further, a combination of in vitro technique and irradiation induced mutagenesis has been recommended to improve cultivars of vegetatively propagated plants (Maluszynski et al., 2000). Some of the selected important agronomical traits of mutant ornamental plants were flower color, flower morphology, flowering time and resistance to abiotic and biotic stress (Das et al., 2000; Misra et al., 2003). The basic requirement for an effective use of irradiation mutation in plant breeding programs is the analysis of radio-sensitivity of the explants material (Walther and Sauer, 1986). Predieri and Gatti (2001) reported that one of the first steps in mutagenic treatments is the estimation of the most appropriate dose to apply.

Therefore, the purpose of the present investigation is to study the effect of gamma rays doses $(0.0,0.5,0.75$, $1.0 \mathrm{~Gy}$ ) to induc mutation on two cultivars (Rosea and alba) of Catharanthus roseus.

\section{MATERIALS AND METHODS}

\section{Source of plant material and In vitro mutagenesis}

Internodes were collected from the cutting of two cultivars of Catharanthus roseus (Rosea and Alba) obtained from previous study (El- Mokadem, 2013). The internode explants were irradiated in a gamma cell with a cobalt 60 source at the National Center of Radiation Research and Technology, Nasr City, Cairo, Egypt. The radiation doses were 0.0 (control), $0.5,0.75$ and $1.0 \mathrm{~Gy}$. Internodes were cut to 5 to $6 \mathrm{~mm}$ long. They were first washed with detergent and distilled water, then disinfected with $15 \%$ chlorine bleach plus two drops of Tween 20 for $15 \mathrm{~min}$, then placed in ethanol $70 \%$ for one minute and rinsed three times with autoclaved distilled water, to ensure that the internodal

\footnotetext{
${ }^{1}$ Department of Floriculture, Ornamental Horticulture and Garden design, Fac. of Agric., Alex. Univ., Alexandria, Egypt. Received Febuary13, 2014, Accepted March 26, 2014
} 
parts (explants) are totally sanitized. Explants were cultured on solidified media containing $4.43 \mathrm{~g} / 1 \mathrm{MS}$ with vitamins (Murashige and Skoog, 1962) supplemented with $30 \mathrm{~g} / 1$ sucrose, $7 \mathrm{~g} / \mathrm{l}$ agar and 4.0 $\mathrm{mg} / \mathrm{l} \mathrm{BA}$, the $\mathrm{pH}$ was adjusted at $5.8 \pm 0.1$. This medium is reported to be the best for shoot formation (El- Mokadem, 2013), which was poured in tubes (2.5 $\mathrm{cm}$ diameter $\times 15 \mathrm{~cm}$ height), Each tube with one explant considered as replication. Ten replications were used for each dose. After culture the explants, tubes were sealed with parafilm and placed under a $16 / 8 \mathrm{~h}$ photoperiod at $21{ }^{\circ} \mathrm{C}$. After one month of incubation, the explants that formed shoots were sub cultured to the same medium but with addition of $1.0 \mathrm{mg} / 1 \mathrm{IAA}$ for root induction.

\section{Transfer of in vitro grown plantlets to greenhouse}

After shoots and roots development, regenerated plantlets were washed with tap water to remove any medium traces from the roots and were transplanted in pots filled with peat moss, perlite and sand (1:1:1 $\mathrm{v} / \mathrm{v} / \mathrm{v})$. The pots were incubated under moist conditions in the greenhouse for acclimatization. Plants in the greenhouse were screened for variation in morphological characters of leaves and flowers.

\section{Statistical design and analysis}

Data were statistically analyzed as a factorial experiment with two factors; radiation dose and cultivar in a randomized complete design (RCD) with 10 replicates (4 gamma ray doses $x 2$ cultivars $x \quad 10$ replicates $=80$ internodes). All obtained data were subjected to analysis of variance (ANOVA) and data with percentage was subjected to arcsine transformation prior to statistical analysis according to Steel and Torrie (1980). Comparisons among means were made using the least significant differences test (LSD) at 0.05 level of probability. The data were analyzed using SAS program version 6 (1985).

\section{RESULTS AND DISCUSSION}

\section{Effect of gamma irradiation on morphological characters}

Plantlets transferred to the greenhouse (after rooting and acclimatization) were screened for variation in the morphological characters.

\section{Leaf variation}

The obtained data of both cultivars showed a wide range of leaf shape abnormalities compared to the leaves of control plantlets which was oblong-elliptic (Fig.1). Plantlets treated with 0.5 Gy gave divided leaf form while, the 0.75 and 1.0 Gy treated plantlets resulted in leaves with wavy margins.

More than one factor may be responsible for such variation in leaf patterns. A possible explanation is that the alteration in the ontogeny of leaf tissues as a result of irradiation is through the selective destruction of one or more cell layer in the shoot meristem (El-Shennawy et al.2011 on Encelia farinosae). Other leaf changes, especially those with distorted patterns of development may be resulted as induced polyploidy as reported by Love (1966) on Euphorbia pulcherrima.

\section{Flower variation}

Among the plants that continued their growth in the greenhouse until flowering, two new colors appeared with the 0.75 Gy dose. One plant from Rosea produced purple colored flowers with white margins compared to the dark purple center and light purple margins of the control flowers (Fig. 2A). As for the Alba cultivar, one plant showed flowers with large pink center compared to the small pink centre and white petals in the control (Fig. 2A).

In the meantime, flower shape variation was observed in both cultivars. The $0.75 \mathrm{~Gy}$ dose caused plants with four petals compared with five ones in the control in both Rosea and Alba (Fig. 3A and B). Also, in Alba cultivar, flowers with four normal sized petals and small one and abnormal petal were obtained with 1.0 Gy irradiation (Fig. 3B).

The obtained results go in line with those reported by Bouman and De Klerk (1996). They examined the extent of variability of leaf shape and flower color in ornamental plants and observed a large increase in variability after regeneration from non-organized callus. In addition, Nagatomi et al. (2000) stated that, the most variability in flower color of the regenerators was induced with gamma irradiation and not by a culturing process. Frequent studies reported the ionizing radiation effects on the shape and form of the floral organs: Smilansky et al. (1986) working on Rosa spp., Soedjone (1989) on Begonia semperflorens, Datta (1990) on Rosa spp., Banerji et al. (1996) on rooted cutting of Chrysanthemum morifolium, Khalaf (2008) on Amaranthus caudatus and El-Shennawy et al. (2011) on Encelia farinosa. They concluded that these changes in flower color might be attributed to the effect of radiation treatments along with the temperature and light influence on the development of pigments. They added that, the phenotypic expression of the genes concerned should be dependent upon the temperature, since temperature is one of the factors controlling reaction velocity.

In addition, Abdel-Maksoud (1992) stated that changes in flower form may be a result of chromosomal deletion or change of the factor governing the normal form or structure, as well as of the effect of gamma-rays on the ontogeny of flower organ tissue through the 
selective destruction of one or more cell layer in the apical floral meristem.

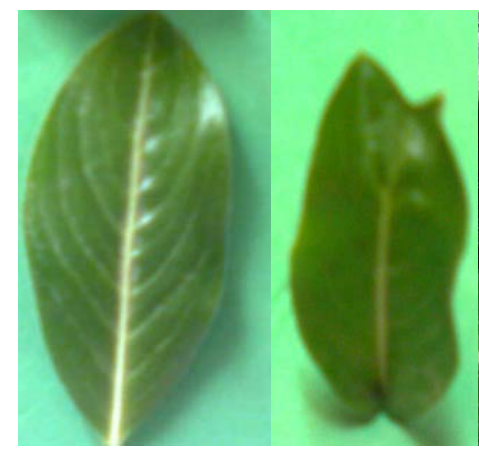

Rosea

Control divided form at $0.5 \mathrm{~Gy}$

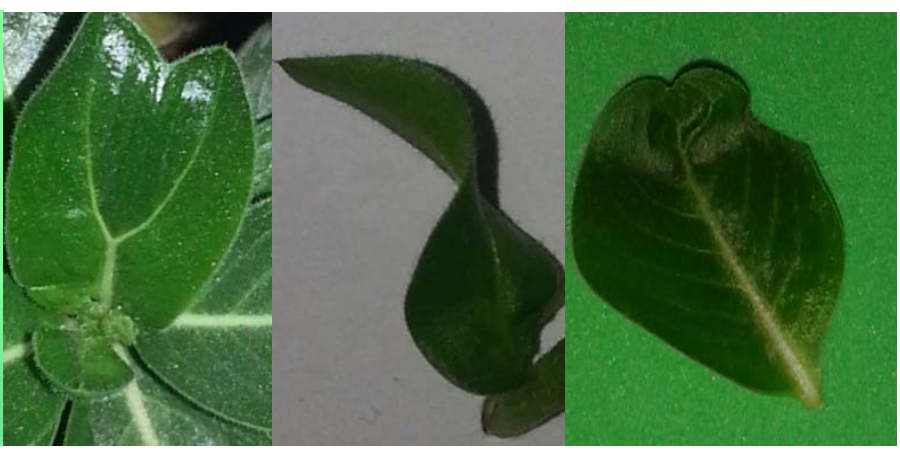

Alba

Fig. 1. The effect of radiation dose on leaf shape variation in the two Catharanthus rosues cultivars

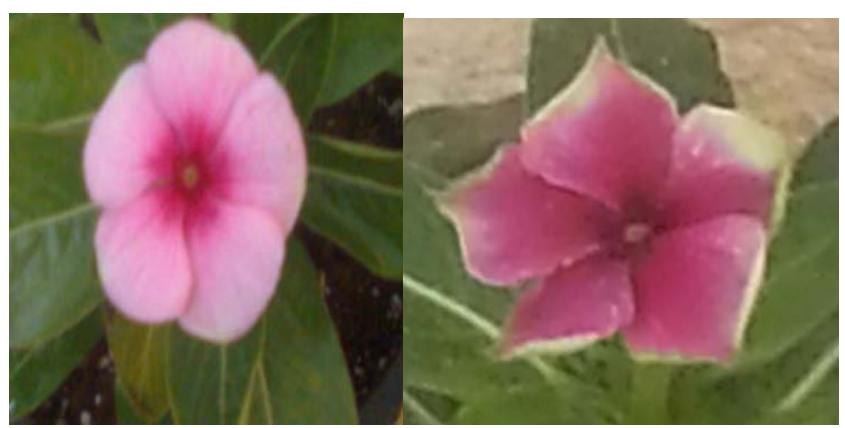

Control

0.75Gy
A. Change in color of Rosea.

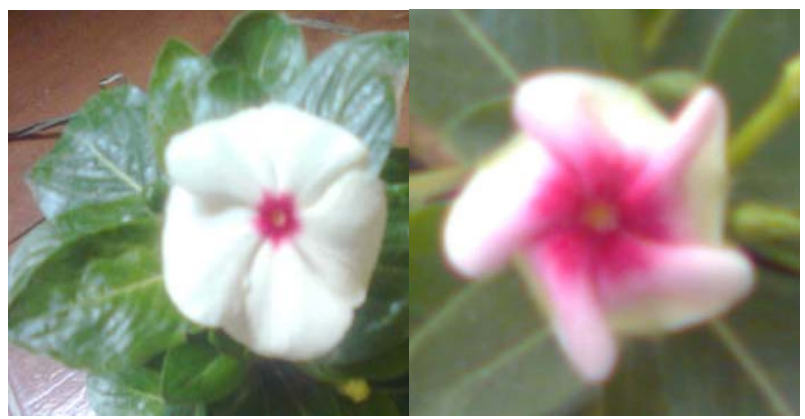

Control

B. Change in color of Alba

Fig. 2.The effect of gamma radiation on flower color variation in Catharanthus rosues cultivars. 

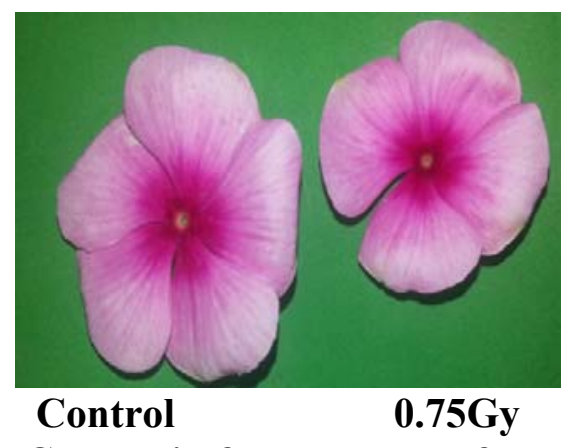

A. Change in flower shape of Rosea

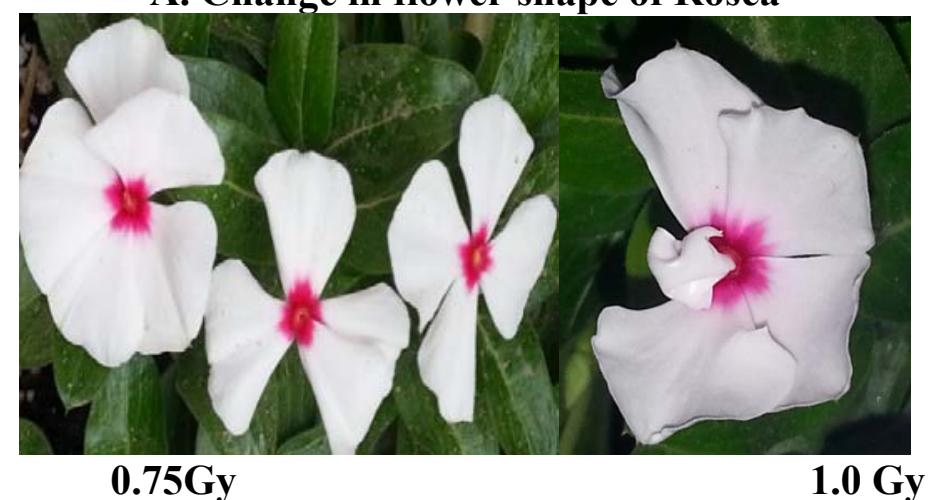

B. Change in flower shape of Alba

\section{Fig. 3. The effect of gamma radiation on flower shape variation in Catharanthus rosues cultivars}

\section{CONCLUSION}

From the obtained results of the present study, it may be necessary to try other doses of irradiation, as well as some chemical mutagens to obtain better phenotypes characteristics of both Rosea and Alba. These new plants will be confirmed by using RAPD to differentiate the regenerated plants from their parents before releasing as commercial cultivars.

\section{REFERENCES}

Abdel-Maksoud, B. (1992). Gamma-rays effect on Solanum pseudocapsicum L., I. The M1- generation. Alex. J. Agric. Res. 37: 227-247.

Banerji, B. K; Dwivedi, A.K.; and Datta, S.K. (1996). Gamma irradiation studies on rose and Chrysanthemum. J. of Nuclear Agriculture and Biology 25 (2) 63-67.

Bouman, H. and De Klerk, G.J. (1996). Somaclonal variation in biotechnology of ornamental plants. In: Geneve R., Preece J., Merkle S. (eds), Biotechnology of Ornamental, pp 165-183.

Broertjies, C.; Roest, S. and Bokelmann, G.S.; (1976). Mutation breeding of Chrysanthemum morifolium Ram.
Using in vivo and in vitro adventitious bud techniques. Euphytica, 25: 11-19.

Broetjies, C.; and Van Harten, A.M. (1978). Application of mutation breeding method in the improvement of vegetatively propagated crops. Elsevier Scientific Publishing Co. 162-175.

Das, A.; Gosal, S.S.; Sidhu, T.S. and Dhaliwal, H.S. (2000) Induction of mutations for heat tolerance in potato by using in vitro culture and radiation. Euphytica 114:205209.

Datta, S.K. (1990). Gamma-ray induced somatic mutations in rose. Mutation Breeding Newsletter 33:17-18. (C.F.plant Breed. Absts. 60: 1024).

De Jong, J. and Custers, J.B.M. (1986). Induced changes in growth and flowering of Chrysanthemum after irradiation and in vitro culture of pedicels and petal epidermis. Euphytica, 35: 137-148.

El-Mokadem, H.E. (2013). In vitro regeneration and somaclonal variation of Catharanthus roseus Don. Using Leaf and Internodal Explants.Alexandria Science Exchange Journal. 34 (4): 452-459.

El-Shennawy, O.;El-Mokadem, H.E.; Abas, R.A.; and Douban, Y.A. (2011). Effect of gamma- irradiation on 
growth, flowering and induced variability in Encelia farinose L. Alex. J. Agric. Res. 56 (3): 63-73.

Huttema, J.B.;M, Preil, W. and De Jong. (1991). Methods for selection of low-temperature tolerance mutants of Chrysanthemum morifolium Ramat. Using irradiation cell suspension cultures. III. Plant Breed., 107: 135-140.

Jain, S.M.; (2005). Major mutation-assisted plant breeding programs supported by FAO/IAEA. Plant Cell Tiss Org Cult. 82:113-123.

Kalaf, W. (2008). Effect of gamma irradiation on growth, flowering and induced variability in Amaranthus caudatus, L. M. Sc. Thesis, Fac. Agric., Alex. Univ., A.R.E.

Love, J.E. (1966). Some effects of fast neutrons irradiation on the somatic tissue of poinsettia. Proc. Amer. Soc. Hort. Sci. 89:672-676.

Maluszynski, M.; Nichterlein, K.; Van Zanten, L. and Ahloowalia, B.S. (2000). Official released mutant varieties-the FAO/IAEA database. Mut Breed 12:1-88.

Misra, P.; Datta, S.K. and Chakrabarty, D. (2003). Mutation in flower colour and shape of Chrysanthemum morifolium induced by $\gamma$-radiation. Biolog Plant 47(1):153-156.

Murashige, T. and Skoog, F. (1962). A revised medium for rapid growth and bioassay with tobacco tissue cultures. Physiol Plant. 15:473-479.

Nagatomi, S.; Miyahira, E. and Degi, K. (2000). Induction of flower mutation comparing with chronic and acute gamma irradiation using tissue culture techniques in Chrysanthemum morifolium Ramat. Proc. $19^{\text {th }}$ Int
Symposium Improvement Ornamental plants. Acta Hort. $508: 69-73$.

Predieri, S. and Gatti, J. (2000). Pear mutagenesis: In vitro treatment with gamma rays and field selection for vegetative from triats. Euphytica 114:79-90.

SAS Institute Inc. (1985) SAS/STAT. Guide for personal computers. Version $6,4^{\text {th }}$ ed. Vol.2 Cary. NC, USA.

Smilansky, Z. Umiel, N. and Zeslin, N. (1986). Mutagenesis in roses (cv. Mercedes). Envir. Exp. Bot. 26: 279-283.

Soedjone, S. (1989). Effect of the technique of gamma-rays irradiation on plant trait variability in Begonia semperflorens. Plant Breed. Absts. 59: 8170.

Steel, R.G.D. and Torrie, J. H. (1980). Principles and procedures of statistics. A Biometrical Approach. $\left(2^{\text {nd }}\right.$ edition). McGraw Hill Book 278-284.

Stewart, R.N and Dermen, H. (1970). Somatic genetic analysis of the apical layers of chimera sports in Chrysanthemum by experimental production of adventitious shoots. Amer. J. Bot., 57: 1061-1071.

Swanston-Flatt.; Day, C.; Flatt, P.R.(1989). Glycaemia effects of traditional Europian plant treatments for diabetes studies in normal and streptozotocin diabetic mice. Diabetes Res. 10(2): 69-73

Walther, F. and Sauer, A. (1986). In vitro mutagenesis in roses. Acta Hort. 189:37-46.

Wang, K.; Mao,Y.; Zhang, X. (1988). Induced mutation for crop improvement in China. Zhong Yao Cai 6:109-115.

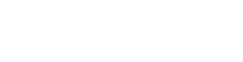

\section{إلستحداثطفرات لنبلتا الونكامعمليا بإستخدلم أثنعة جاما$$
\text { هلى المبيد التهن }
$$

( o.0, 0.5, 0.75 , 1.0 Gy)

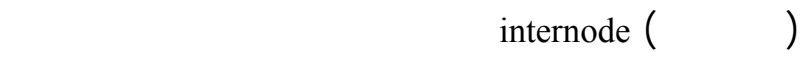

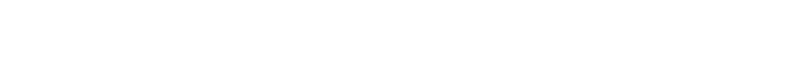

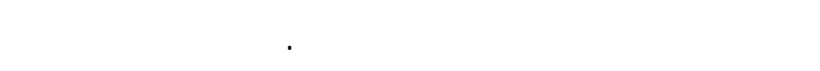

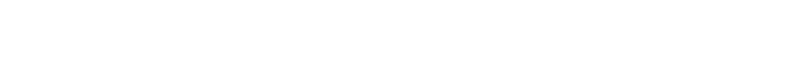

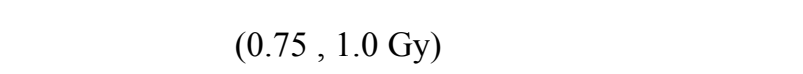

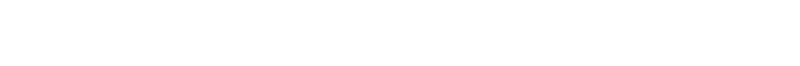

الجرعتلن (0.5 , 1.0 Gy) الأكثر تأثيرا فى إحداث تغي ـرك

فهشك الورقة وذك فى كلا الصفين.
مُ زراعة نباتلت الونكا معمليا ببلستخدله ص فنين م ن

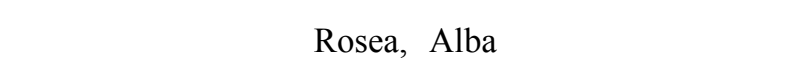

النبات Internode (للسلاميت) حيث أعطى أفضل نتائج فى إنتاج المجلمبع الخضرية ومة أيضا تحديد أفضل بيئة غذائية

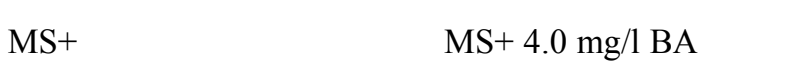
1.0 mg/l IAA + 4.0 mg/l BA أعلى معل جذور. (El Mokadem,2013).

مُ م إجراء هذه التجربة حيث مُ تعريض اللد للاميت

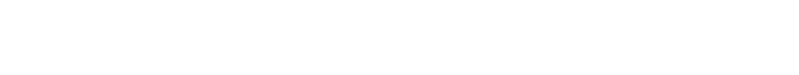

